Daniel Weidner · Sigrid Weigel (Hrsg.)

Benjamin-Studien 1 

Daniel Weidner · Sigrid Weigel (Hrsg.)

Benjamin-Studien 1 
Bibliografische Information der Deutschen Nationalbibliothek

Die Deutsche Nationalbibliothek verzeichnet diese Publikation in der Deutschen Nationalbibliografie; detaillierte bibliografische Daten sind im Internet über http://dnb.d-nb.de abrufbar.

Alle Rechte, auch die des auszugsweisen Nachdrucks, der fotomechanischen Wiedergabe und der Übersetzung, vorbehalten. Dies betrifft auch die Vervielfältigung und Übertragung einzelner Textabschnitte, Zeichnungen oder Bilder durch alle Verfahren wie Speicherung und Übertragung auf Papier, Transparente, Filme, Bänder, Platten und andere Medien, soweit es nicht $\$ \$ 53$ und 54

URG ausdrücklich gestatten.

(C) 2008 Wilhelm Fink Verlag, München

(Wilhelm Fink GmbH \& Co. Verlags-KG, Jühenplatz 1, D-33098 Paderborn)

Internet: www.fink.de

Layout: Marietta Damm, Zentrum für Literatur- und Kulturforschung Berlin Einbandgestaltung: Evelyn Ziegler, München

Printed in Germany

Herstellung: Ferdinand Schöningh GmbH \& Co KG, Paderborn

ISBN 978-3-7705-4637-4 


\title{
Benjamin's »-abilities«: Mediality and Concept Formation in Benjamin's Early Writings
}

\begin{abstract}
Although Walter Benjamin was never timid when it came to writing, one practice he consistently avoided was that of creating neologisms. ${ }^{1}$ It is therefore with all the more reluctance that I find myself compelled to resort to something similar, in order to sum up a motif that has imposed itself over the years in my reading of Benjamin. What is involved is, to be sure, not exactly a neologism, since it does not involve the creation of a new word, but rather the highlighting of a word-part, a suffix (eine Nachsilbe). In English, to be sure, this suffix, when spoken, is indistinguishable from a word: what distinguishes it from a word is not audible, but only legible: a hyphen, marking a separation that is also a joining, a Bindestrich that does not bind it to anything in particular and yet that requires it to be bound to something else. The suffix in question thus sounds deceptively familiar, since it coincides, audibly, with the word "abilities". However, unlike that word, its first letter - which purely by accident happens to be the first letter of the alphabet--is preceded by a dash. When written in isolation, this gives it a somewhat bizarre appearance, to be sure, since suffixes are not usually encountered separately from the words they modify. But this bizarre appearance pales when compared to its German ıoriginalı. If the book of essays to be published in English under the title, »Benjamin's -abilities, « is ever translated into German - »back» into German I was tempted to write, since German here is of course the language in which Benjamin wrote and in which I generally read him - then its title, were it to be entirely faithful to the English, would indeed have to involve the creation of a neologism. For translated back into German, the German title would require its readers to »read, what was never written«, namely: »Benjamins -barkeiten« (written, »Bindestrich - b--kleingeschrieben«).
\end{abstract}

1 „Die Einführung neuer Terminologien, soweit sie nicht streng im begrifflichen Bereich sich halt, sondern auf die letzten Gegenstände der Betrachtung es absieht, ist daher innerhalb des philosophischen Bereichs bedenklich. Solche Terminologien [...] entraten der Objektivität, welche die Geschichte der Hauptprägungen der philosophischen Betrachtungen gegeben hat.« W. Benjamin: Ursprung des deutschen Trauerspieles, GS I.1, p. 227. Dieser Text ist in veränderter Form auch erschienen in: Samuel Weber: Benjamin's -abilities, Cambridge (Harvard UP) 2008. 


\section{SAMUEL WEBER}

Let me, then, in what follows, begin to try to explain, if not justify this bizarre title, whether as "Benjamins -barkeiten« or as "Benjamin's -abilities«, by first of all tracing it back to what is a double - or split - origin. The first aspect is fairly obvious, at least to anyone who has read much of Benjamin's writings. Throughout his life, Benjamin tended to formulate many of his most significant concepts by nominalizing verbs, not in the usual manner but by adding the suffix -barkeit (which in English can be written either -ibility or -ability: for the sake of simplicity and clarity, I will in English use only the latter Schreibweise). To recall just the most prominent of these -barkeiten or abilities - and there are many more lurking in all corners of his texts, one of which I will discuss later in this talk (chapter) - I will mention only the following: Mit-teil-barkeit (from his 1916 essay on the "Die Sprache...»), Kritisier-barkeit (from his dissertation on »Der Begriff der Kunstkritik in der deutschen Romantik, published in 1920), Übersetz-barkeit (in »Der Aufgabe des Übersetzers«, 1923), Reproduzierbarkeit, (in »Das Kunstwerk im Zeitalter seiner technischen Reproduzierbarkeit«, 1935), and finally, Erkenn-barkeit - part of the title of our Conference - but also Les-barkeit in Notebook " $\mathrm{N}$ « of the manuscripts concerning the Paris Passages. This widespread and persistent tendency to form concepts by recourse this suffix, which even in German produces rather awkward nouns, provided a first indication that more had to be involved here than merely stylistic idiosyncrasy.

That was the first origin of my fascination with Benjamin's -barkeiten. A second inspiration came from quite a different source, although from one that was for me always profoundly related to Benjamin's writing. I am speaking of the work of Jacques Derrida, and in particular of his celebrated - or notorious, depending on your perspective - polemical exchange with the philosopher, John Searle. Since I was involved in the English translation of what was to become known as "Limited Inc... «, I remember being especially impressed by one moment in Derrida's rejoinder to Searle's critique of an essay he had written on John Austin, the founder of speech-act philosophy. For those of you who have forgotten or who never read through the exchange, let me briefly recall the context: In 1972 Derrida had published a reading of Austin under the title, "Signature, Event, Context«. The text was translated and published in English some years later. Soon after word got around that Searle considered this essay extremely weak. He was therefore invited to respond to Derrida publicly, which he did, in a short text, to which Derrida in turn replied, but in an essay of over 100 pages, entitled "Limited Inc... « One of the central issues involved the relation of spoken to written language, and in particular, the role of the subject in relation to both. Searle's critique made it clear that he understood Derrida as claiming that a key difference 
between written and spoken language has to do with the absence or presence of the subject. As Searle put it, thinking he was thereby correcting Derrida:

Writing makes it possible to communicate with an absent receiver, but it is not necessary for the receiver to be absent. Written communication can exist in the presence of the receiver, as for example, when I compose a shopping list for myself...2 In replying, Derrida brought to the fore a term that would remain throughout his subsequent writings as one of their few constants--a sort of deconstructive "principle«, if such were not a contradiction in terms; the term »iterability«:

The response is easy and clear. Sec [Abbreviation used by Derrida for his essay on Husserl: Signature, Event, Context] never said that this absence is necessary, but only that it is possible [...] and that this possibility must therefore be taken into account: it pertains, qua possibility, to the structure of the mark as such, i.e. to the structure precisely of its iterability. ${ }^{3}$

It is in elaborating the nature of the "possibility" implied in the notion of »iterability" that Derrida explains why »iterability« must not be confused with »iteration« but rather involves a very distinctive mode that is difficult to situate in terms of the traditional opposition - and hierarchy - that subordinates "possibility« to »reality« or »actuality«:

If one admits that writing (and the mark in general) must be able to function in the absence of the sender, the receiver, the context of production etc., this implies that this power, this being able, this possibility is always inscribed, hence necessarily inscribed as possibility in the functioning or the functional structure of the mark. [...] It follows that this possibility is a necessary part of its structure. [...] Inasmuch as it is essential and structural, this possibility is always at work marking all the facts, all the events, even those that appear to disguise it. Just as iterability, which is not iteration, can be recognized even in a mark that in fact seems to have occurred only once. I say seems, because this one time is in itself divided or multiplied in advance by its structure of repeatability. ${ }^{4}$

Iterability, the power or potentiality to repeat or be repeated, is not the same as repetition, precisely because it is a structural possibility that is potentially "at work" even there where it seems factually not to occurred. A »mark « can only be identified, which is to say, apprehended as such, only by virtue of its being repeated, at least mentally, and compared to its earlier occurrence. Memory and repetition are thus constitutive elements of identity,

\footnotetext{
Jacques Derrida: Limited Inc, Evanston (Northwestern University Press) 1988, p. 47.

Ibid.

4 Ibid., p. 48 (emphasis S.W.).
} 
which depends on iterability - that is to say, on the ability of any event to be iterated, repeated. The possibility of such repetition entails both alteration and sameness - sameness through alteration. This means that identification is only possible by averting one's regard, as it were, from what changes in order to apprehend what stays the same over time and space. As we shall see, something very similar also marks Benjamin's -abilities.

To be sure, Derrida's "ability« here is not simply that of Benjamin's. Nevertheless, his distinction between »iterability« and »iteration«, »repeatability« and »repetition «, [between] empirically observable fact and structural possibility, can tell us much about Benjamin's penchant for forming key concepts in terms of their -ability, rather than their actuality, as mere facts. Moreover, to argue, as Derrida does in the passage quoted, that this potentiality or ability involves a process by which what is ostensibly a single occurrence finds »itself divided or multiplied in advance by its [...] repeatability« is to undercut the usual definition of possibility itself, which ever since Aristotle has understood to be a mode of actuality or of actualization, and thus has been defined by opposition to its negation, impossibility, which it is held to exclude. As we will see, this either-or binary logic does not hold for Benjamin any more than it does for Derrida.

Given this divided or double path by which the notion of "-ability, " and in particular, its significance for Benjamin, imposed itself on me, it will not be surprising that the "-abilities" with which I am concerned cannot be considered as being the properties or attributes of a particular subject, Walter Benjamin, no matter how genial and fascinating that subject undoubtedly was. But what continues to provoke today, I am convinced, has less to do with the person of Walter Benjamin than with his writings, even if it is clear that one cannot fully separate the two. If those writings surprise us again and again by their seemingly inexhaustible ability to come up with unexpected, surprising and above all formulations and insights, however enigmatic these may be, then I want to suggest that this is in part, at least, the result of a very distinctive way of conceptualizing that manifests itself in the tendency to resort to the suffix, -ability - »-barkeit « - in forming nouns from verbs. This mode of conceptualizing "virtualizes" the process of nominalization by referring it back to what in German is very appropriately designated as a Zeitwort: a verb that is inseparable from time insofar as it involves an on-going, ever-unfinished and unpredictable process: Erkennbarkeit thus names the virtual condition of Erkennen, Benennbarkeit that of Benennen, Kritisierbarkeit that of Kritisieren etc.

In his "Epistemo-critical Preface» to the Trauerspiel-Book, Benjamin attempts to determine the specific mediating function (Vermittlerrolle) of the concept with respect to phe- 
nomena, on the one hand, and the idea on the other. (GS I.1, 214ff.) The latter can only be presented or staged - dargestellt - by taking leave of the realm of pure ideas and descending to that of empirical, phenomenal experience, and this in turn can be accomplished only through a reordering or reorganization, a dismantling and dispersion effectuated by the concept upon the "thing-like elements" (dinglicher Elemente) that constitute the phenomena. The concept accomplishes this rearrangement, which Benjamin designates as "virtual" - "virtuelle Anordnung" - by decomposing - today we might even dare to say "deconstructing" - the preexisting empirical organization of the phenomena, thus allowing them to reorganized, albeit only "virtually«. Moreover, Benjamin is quite precise in his account of how the concept accomplishes this decomposition and dissemination. It does this by departing from its traditional role of establishing sameness - which is to say, by identifying those traits of the phenomenon that makes it similar to others, so that it can then be subsumed under an average common denominator; instead, the role of the concept as Benjamin understands as practices it is to discern not what makes phenomena like one another but rather what separates and distinguishes them from others. The notion that Benjamin introduces here, in contradistinction to that of average - Durchschnitt - is that of the extreme. In the passages where he elaborates this term - which recurs frequently in the Preface to the Trauerspiel-book - Benjamin never defines or analyzes it. But what emerges from his use of the word is that he is using it quite literally as a term: which is to say, to stress that the delimitation of a phenomenon depends upon a certain process of termination, through which it both occludes and exposes the outer edge of its scope, its Tragweite, thereby stabilizing itself, but only by gesturing toward what it excludes. The extreme, which it is the task of the concept to activate, thus marks the point where a phenomenon is constitutively implicated in what it is not, in what is other and external, in what resists comprehension and containment. The concept, one could say, dismantles the phenomenon by exposing it as a term, in the linguistic sense, but also in the semantic one. The concept de-terminates the phenomenon, and thus allows it to part company with itself. The phenomenon is determined as a "thing « - decomposed into its "thing-like elements" which have then the potential, the ability, to recombine to form something else.

And yet, it is also the function of the concept not just to transform phenomena, but also, in so doing, to "save« them. This notion of "saving" is extremely complex, and this is not the place to go into it in detail. Let me just note that it does not imply simply staying the same over time. This would be the aim of the subsumptive concept, which aims to save the individual by subordinating it to a more general average, that is less vulnerable to alterations of time and space. Benjamin clearly rejects this notion of the concept: »Das 


\section{SAMUEL WEBER}

Allgemeine als ein Durchschnittliches darlegen zu wollen, ist verkehrt" (GS I.1, 215), he writes. The »idea«, which is his term, in the Epistemo-critical Preface« for the alternative use to which the concept is to be put - the idea is affirms the uniqueness of a certain singularity: "Als Gestaltung des Zusammenhanges, in dem das Einmalig-Extreme mit seinesgleichen steht, ist die Idee umschrieben" (ibid.). The "virtual rearrangement" of phenomena by concepts into terms thus links their de-termination with their singularity, as "das EinmaligExtreme«. In dissolving complex phenomena into their elements by taking these to their extremes, the concept reveals not what they share in common, what makes them like other phenomena, their average, but rather what separates them, distinguishes them and makes them »einmalig-extrem «: once-and-for-all. ${ }^{5}$

The power of conceptualization, in this perspective, then, is one of singularization. In taking phenomena to their ever singular extreme, the concept leads them to part company with themselves, with their Self, not in order to dissolver them in some greater generality, but rather to reveal their distinctive, incommensurable spatial-temporal singularity.

But this conceptual »rearrangement" or »reordering" (Anordnung) remains both »virtual« and an »order« in the sense of a command, or better: a challenge, since what results is a configuration that can never be fully self-present, since such a presence would reduce the uniqueness - das Einmalige - by treating it as though it were identically or essentially repeatable as the same. It is only in the convergence of appearance and disappearance, of coming-to-be and passing-away, like the éclair of Baudelaire's "passante« - but also like those three dots or periods that separate the flash from its reflection (»un éclair ... puis la nuit»)--that such phenomena can be "saved«. Such »salvation« can therefore be named most precisely, in English at least, as: coming to pass. What is "saved" is not preserved unchanged, but only in the traces of what comes to pass.

This is why the "idea" can only be "circumscribed « - umschrieben - but never simply beschrieben, described. For the idea is not simply visible or describable, except perhaps in the literal sense of writing and language: "Die Idee ist ein Sprachliches, und zwar im Wesen des Wortes jeweils dasjenige Moment, in welchem es Symbol ist." (GS I.1, 216) This "symbolic side« is however always "more or less hidden«. Since however language must have a phenomenal existence, its hidden »symbolic« and »ideational« dimension is never present in pure form, but always associated with a »manifestly profane significance«. »The task of

5 "Une fois pour toutes« is an expression that imposes itself on and in Derrida's later writings, precisely for the way in which it links singularity, in its uniqueness - its "one-time-ness «--to a certain generality. For a discussion of Derrida's affection for (and by) this expression, see: Samuel Weber: "Toward a Politics of Singularity: Protection and Projection, « in: Hent de Vries (Ed.): Religion Beyond a Concept, New York (Fordham University Press) 2008, pp. 626-646. 
philosophy — since it cannot claim to reveal directly (offenbarend zu reden) - consists in a certain kind of archaic listening [Urvernehmen] which in turn entails remembrance. Through such remembering words are »once again" given the ability »to reassert their rights to name«.

This is why neologisms - which however also entail a certain naming--are to be avoided: for in naming new words, they ignore the historical memory of language. Rather than investing words, Benjamin's discussion, and his writing practice, advocates the reinscribing of established terms so that they part company with themselves - which is to say, with their previous identities. It is by virtue of such a movement of parting-with that words recover the ability to name, which is never reducible to any identifiable semantic content, least of all to that of a proper noun.

If the "presentation of an idea" can therefore never be fully accomplished, if it must remain virtual, one way of a naming that does not invent but rather virtualizes is precisely that of making familiar terms depend on an adjunct, on a Nachfolge which de-termines those words by making them depend on their Nachgeschichte: awakening them to new life in the Nach- or Fortleben of a Nachsilbe. This, perhaps, begins to explain Benjamin's penchant, inclination, or even obsession with his -barkeiten.

To be sure, such -abilities are not Benjamin's alone. For the use of this suffix to form key concepts is by no means a practice invented by Benjamin invented. Formation of philosophical concepts through the use of the suffix, -barkeit, marks the work of the thinker who had doubtless the greatest philosophical influence on Benjamin's thought, at least in its early, formative years. I am of course speaking of Kant. Benjamin's admiration for Kant was "extreme« in the sense already alluded to: not simply as the thinker of a philosophical system, but as one who struggled to push philosophy to its extreme, as the following passage from a 1917 letter to Scholem attests:

Wer nicht in Kant das Denken der Lehre selbst ringen fühlt und wer daher nicht mit äußerster Ehrfurcht ihn mit seinem Buchstaben als ein tradendum, zu Überlieferndes erfaßt (wie weit man ihn auch später umbilden müsse) weiß von Philosophie gar nichts. Deshalb ist auch jede Bemänglung seines philosophischen Stils pures Banausentum und profanes Geschwätz. (Letter to Scholem, 22.10.1917, GS II.3, 937)

Nowhere perhaps is the tradition that Benjamin alludes to here, including its potential for Umbildung, more in evidence than in the last of Kant's "critical « works, usually translated in English as the Critique of Judgment. The word used by Kant in his title, of course, is 


\section{SAMUEL WEBER}

Urteilskraft, a term that the most recent English translator has rightly reminded his readers signifies not judgment but the "power" or "ability « to judge. ${ }^{6}$ The contrast between the German title of the Third Critique, which names a "Kraft, " and that of the first two Critiques, which name a species of reason ("pure» or "practical«), underscores the ambiguous mode of being of the main object of Kant's last Critique: a use of "judgment « that is not really a "judgment « at all, in the traditional sense, but something far more difficult to qualify, since "aesthetic judgment « claims the universal validity otherwise reserved for cognitive "judgments", but without conveying any knowledge at all. It is in this Third Critique, where Kant addresses the problem of whether there are a priori and universally valid rules governing the representation of radical singularities - which is to say, of events that do not fit in or under the available stock of general concepts (as in so-called »determining judgments«) - that he resorts at certain key points to the kind of conceptual formation with which we are concerned here. I will limit myself to recalling briefly two of them, since both will find echoes in Benjamin's early writings as well [even though in this talk I will only have time to deal with one of them].

Toward the end of the Introduction to the Critique of Judgment, Kant sums up the relation of the three "faculties" - and therefore of his three Critiques - as follows:

Der Verstand gibt, durch die Möglichkeit seiner Gesetze a priori für die Natur, einen Beweis davon, daß diese von uns nur als Erscheinung erkannt werde, mithin zugleich Anzeige auf ein übersinnliches Substrat derselben; aber läßt dieses gänzlich unbestimmt. Die Urteilskraft verschafft durch ihr Prinzip a priori der Beurteilung der Natur, nach möglichen besonderen Gesetzen derselben, ihrem übersinnlichen Substrat (in uns sowohl als außer uns) Bestimmbarkeit durch das intellektuelle Vermögen. Die Vernunft aber gibt eben demselben durch ihr praktisches Gesetz a priori die Bestimmung; und so macht die Urteilskraft den Übergang vom Gebiete des Naturbegriffs zu dem des Freiheitsbegriffs möglich. ${ }^{7}$

Kant's effort to find an a priori principle that would allow »nature» to be »judged « even in its most heterogeneous particularity - which here is also its singularity - involves nothing more or less than establishing the determinability - Bestimmbarkeit - of nature as it is in

6 "In this translation, expressions like sthe power of judgment, « the power of thought, « the power of concepts, the power of desire, and so on, always refer to an ability (a "faculty" in that sense). In such expressions, spower is never used to mean anything like strength or forcefulness (of concepts, desire, and so on.)." Werner Pluhar: translator of: Kant: Critique of Judgment (Indianapolis [Hackett] 1987), p. 3, fn. 3. Five years earlier, the French translation of the Third Critique, by A. Philonenko, had already taken notice of this difference: Critique de la faculté de juger (Paris [Vrin] 1982).

7 Immanuel Kant: Kritik der Urteilskraft, Einleitung, IX (Frankfurt a.M. [Suhrkamp] 1981), p. 108. English: p. 37. 
and of itself, which is to say, in its "supersensible substrate«. And yet, as is clear from the passage just quoted, such determinability is to be distinguished from actual determination, since nothing in nature is effectively determined by the ability to judge. No objective concept is produced or invoked, nothing is cognized. Only an abstract principle is produced-purposiveness without purpose - which however demonstrates its universal validity as principle through its link to two other-abilities. The first is perhaps the strangest of all-barkeiten, for it is the one most clearly separated from any subjective faculty. It is the term, Unmittelbarkeit, in English: immediacy (the -ability disappears in this translation). In an aesthetic judgment of taste, of beauty or of the sublime, the pleasure or displeasure called up is immediately attached to the judgment, without mediation of a concept. Normally, this immediate link of pleasure or displeasure to a representation would mark it as strictly subjective, in the sense of individual, empirical and of limited validity. However the pleasure or displeasure attached to an aesthetic judgment of taste claims universal validity despite or rather because of this immediacy. Its ability to stake this claim depends on the third major ability of Kant's Third Critique, and it is one that we will find echoed, albeit transformed, in the early writings of Benjamin. This term is Mitteilbarkeit, usually translated in English as "communicability«, but which might be more accurately rendered as »impartability". An even more literal translation would be the ability to part-with; but given the difficulty of actually using this phrase, I will limit myself to the first two translations.

In the Third Critique, such "communicability» or »impartability» is what takes the place of the objective, conceptual universality that defines judgment in the familiar sense, involving the determination of the particular by the general. In the case of what Kant designates as "reflecting judgments", including the "aesthetic judgments of taste", the particular is not determined but only experienced as determinable insofar as feelings of pleasure (or displeasure) associated with its apprehension are felt to be immediately and universally communicable. But just as he distinguished determinability from determination, Kant distinguishes communicability from actual communication:

Es kann aber nichts allgemein mitgeteilt werden, als Erkenntnis und Vorstellung, sofern sie zum Erkenntnis gehört. ${ }^{8}$

Nothing relating to knowledge is actually communicated in the aesthetic judgment of beauty or of the sublime: rather, a certain state of mind (Gemütszustand) that is felt to be indissolubly linked to a singular representation is experienced as being potentially com-

8 Ibid., p. 131. English: p. 61. 
municable, which is to say, capable of being communicated universally. This experience is in turn associated with pleasure or displeasure.

In these two instances, then, Kant invokes his -abilities as a possibility that is not merely a mode of or means to actualization, but rather to define an experience that is related to cognition but is nevertheless non-cognitive; indeed, it could be called affective, although Kant does not use this term, since it involves a "feeling " or a "state of mind" that is produced from without: from the encounter with a singularity that is apprehended, perceived or represented in a way that renders it universalizable.

Both of these two Kantian -abilities--Bestimmbarkeit and Mitteilbarkeit--reemerge in Benjamin's early writings, but with a decisive shift: for now they are situated not primarily within a horizon of knowledge, but within one of language. ${ }^{10}$ [Today I will only have time to deal with the first of these].

Determinability appears in Benjamin's essay on »Two Poems of Friedrich Hölderlin«, written in the winter of 1916-17. I will limit my discussion to the specific way in which this Kantian -ability is reinscribed by the young Benjamin, mindful of the fact that this question would by rights require a much more elaborate account than I can give here.

Let me begin by anticipating the result of the discussion. Whereas in Kant, the effort is to describe abilities as constituting the conditions of a possibility in view of its full realization - even if that realization can never be fully accessible to knowledge--for Benjamin the primary question no longer concerns Erkenntnisvermögen but rather the potentialities of language, which, qua signifying process, entail impossibility no less than possibility. This difference can be interpreted negatively, as the impossibility of ever realizing, in a full and self-present act of cognition, the "abilities« involved; or it can be interpreted positively, as a virtuality that, precisely because it cannot ever hope to be fully instantiated or exhausted in any one realization, remains open to the future, which is to say, to what Benjamin in the title of another essay of this period, calls das Kommende (Über das Programm der kommenden Philosophie $\left.{ }^{11}\right)$. In other words, already in these early writings, the "Jetzt der Erkennbarkeit« is implicitly distinguished from anything like a meaningful present, which

9 Thus, in $\$ 9$, Kant explains that it is not the feeling of pleasure or displeasure that grounds the communicability, but the "allgemeine Mitteilungsfähigkeit des Gemütszustandes in der gegebenen Vorstellung, welche, als subjektive Bedingung des Geschmacksurteils, demselben zum Grunde liegen, und die Lust an dem Gegenstande zur Folge haben muß.«(Ibid., p. 131).

10 In a letter to Scholem written shortly after the two essays we are about discuss, namely in 1917, Benjamin asserts that "for me question regarding the essence of knowledge, right, art are related to the question of the origin of all human intellectual manifestations (Geistesäußerungen) in the essence of language. (GS II.3, p. 932)

11 GS II.1, pp. 157-171. 
is also why it cannot be identified with an object of knowledge. Benjamin is thus faithful to the Kantian distinction between "thinking " and "knowing" - perhaps more faithful than Kant himself. ${ }^{12}$ It entails a virtuality that is never fully actualizable and therefore involves an "experience« that involves movement and alteration rather than reproduction of the same - or of the self.

Turning now to the essay on Hölderlin, Benjamin introduces the term, Bestimmbarkeit, in the opening pages, when he attempts to define his procedure, which he designates as an "aesthetic commentary" [ästhetischer Kommentar] (GS II.1, 105), aimed at elaborating the »inner form « of the two poems involved. This »inner form « he then goes on to identify with the "poetic task" (dichterische Aufgabe), in which the "evaluation" of the poem by the critic is grounded. What is decisive here, Benjamin insists, is not the degree to which the poet has accomplished this poetic task, but rather "the seriousness and greatness of the task" itself. This task has to be derived from a reading of the poem, although at the same time and here a certain circularity emerges - it serves as the "condition" (Voraussetzung) of the poem, "as the intellectual-sensual (geistig-anschaulich) structure of the world to which the poem bears witness«. (105)

Benjamin does not explicitly discuss the circularity that here begins to appear, between task, poem and commentary, but he clearly rejects any attempt to resolve such circularity by recurring to empirical instances, such as the "person or world-view of the creator". In place of this traditional appeal to an authorial intention or person, he introduces the term that will guide him in his introductory methodological discussion: The »sphere that is both "product and object of the investigation" can neither be equated with the poet, nor with the poem: "This sphere, which for every poem (Dichtung) has its own shape (Gestalt) shall be designated as the poetized [das Gedichtete]. This sphere of the "poetized ", in which Benjamin situates the "truth" of the poem (and of poetry: Dichtung), is thus peculiar to each singular poem, and receives its particular "shape« as its »inner form «.

But if the poetized is thus manifested as the inner form of the poem, it is not entirely inherent in it either. Rather, Benjamin describes it as a »borderline concept« [Grenzbegriff],

12 „Einen Gegenstand erkennen, dazu wird erfordert, daß ich seine Möglichkeit (es sei nach dem Zeugnis der Erfahrung aus seiner Wirklichkeit, oder a priori durch Vernunft) Beweisen könne. Aber denken kann ich, was ich will, wenn ich mir nur nicht selbst widerspreche, d.i. wenn mein Begriff nur ein möglicher Gedanke ist, ob ich zwar dafür nicht stehen kann, ob im Inbegriffe aller Möglichkeiten diesem auch ein Objekt korrespondiere oder nicht. Um einem solchen Begriffe aber objective Gültigkeit (reale Möglichkeit, denn die erstere war bloß die logische) beizulegen, dazu wird etwas mehr erfordert. Dieses Mehrere aber braucht eben nicht in theoretischen Erkenntnisquellen gesucht zu werden, es kann auch in praktischen liegen." Immanuel Kant: Kritik der reinen Vernunft, Vorrede zur zweiten Auflage, B XXVI, Hamburg 1960, pp. 25-26. 


\section{SAMUEL WEBER}

and this in a "dual respect « (doppelter Hinsicht). The first, and most obvious aspect concerns the poem itself. The "poetized" is a borderline concept with respect to the "poem", from which it distinguishes itself as a "category of aesthetic investigation" (ästhetischer Untersuchung). On the other side of the »border" is »life«, which Benjamin also identifies with the "poetic task". Thus, as borderline concept, "the poetized reveals itself to be the transition from the functional unity of life to that of the poem«. (GS II.1, 107) However, if Benjamin can write that »life is the poeticized of the poem« (107), it is not the personal life of the poet that is meant but rather a "context of life (Lebenszusammenhang) determined through art«.

The question then becomes just how »art « - here the poem - »determines" the "context of life«. And so, it is no wonder that the category of "determination« - Bestimmung - is at the core of Benjamin's discussion of the poems, and also the basis of his contrasting evaluation of them. There is no time to go into the details of that evaluation here, and it is also not my main concern. Rather, it is the ability to determine and be determined that interests me in our context, and it is precisely this term - Bestimmbarkeit--that Benjamin invokes to distinguish the poetized - das Gedichtete, sphere of the poem's truth - from the poem itself, as well as from "life«, that sets it its "task«. After having asserted that the Gedichtete shares with the poem itself the unity of form and content, Benjamin goes on to attempt to describe the decisive distinction between the two as a difference not in "principle«, but rather in degree. However, this degree turns out to be of a rather unusual, non-quantitative kind:

Vom Gedicht unterschieden ist es [das Gedichtete] als ein Grenzbegriff, als Begriff seiner Aufgabe, nicht schlechthin noch durch ein prinzipielles Merkmal. Vielmehr lediglich durch seine größere Bestimmbarkeit: nicht durch einen quantitativen Mangel an Bestimmungen, sondern durch das potentielle Dasein derjenigen, die im Gedicht aktuell vorhanden sind und andrer. Das Gedichtete ist eine Auflockerung der festen funktionellen Verbundenheit, die im Gedichte selbst waltet, und sie kann nicht anders entstehen als durch ein Absehen von gewissen Bestimmungen; indem hierdurch das Ineinandergreifen, die Funktionseinheit der übrigen Elemente sichtbar gemacht wird. (GS II.1, 106)

The stylistic movement of this passage strikes me as extremely characteristic of what I would call the discontinuous mode of argumentation that marks so many of Benjamin's texts. ${ }^{13}$ It also explains why he should have been so appreciative of Kant's torturous, if

13 Such discontinuous argumentation is formalized in his account of "philosophical style» in the EpistemoCritical Preface to the Trauerspiel-book: "Der Begriff des philosophischen Stils ist frei von Paradoxie. Er hat seine Postulate. Es sind: die Kunst des Absetzens im Gegensatz zur Kette der Deduktion; die Ausdauer 
not tortured philosophical style of writing, which as we have seen he defended against all criticism. If such barely grammatical phrases could be seen as emblematic of the "Ringen« - the struggle - that Benjamin so valued in Kant, the same can be discerned in his own writing, and perhaps particularly in those texts that were never published in his lifetime, such as the essay on Hölderlin. For in those texts Benjamin allows himself to think things through to an extreme that he cannot necessarily resolve or synthesize into grammatically or stylistically "correct « formulations and phrases. That is particular in evidence here, at the end of the second sentence quoted, where Benjamin strives to describe positively wherein the distinctive quality of the poetized resides. He has already stated what it does not consist in: it does not consist in a "prinzipielles Merkmal but rather in a "greater determinability«; however, that »determinability« is not "greater« in a simply quantitative sense. On the contrary, if one can take Benjamin's formulation here literally, it seems as if the poetized has fewer determinations than does the poem. But those fewer determinations nevertheless contribute to a "greater determinability«. How is this possible? Precisely through the predominance of possibility in the poetized, which is constituted by the "potential existence" (potentielles Dasein) of determinations that in the poem are "actually present" (aktuell vorhanden). This is also why the poetized does not distinguish itself from the poem by any "principle mark or trait" (prinzipielles Merkmal). For there is nothing "principled" about the poetized: it merely takes its cue from the poem - or looking ahead, to the essays on the "Task of the Translator " and on "The Work of Art in the Age of its Technical Reproducibility« - we could also say that it takes its cue from its »original«. However it does so, already here, in a way that anticipates and perhaps even transcends many of the theorems unfolded in the later essays. For the "potential " determinability of the poetized virtualizes not merely the determinations that are actually present in the poem, but "others" as well. It is here that we stumble upon the most awkward formulation of the entire essay, one that Benjamin would perhaps have expunged had he revised it for publication. But he did not do so, and what remains is as denkwürdig as it is stylistically and philosophically monstrous. Since you probably did not notice it when I cited it the first time, here is the sentence again, in which Benjamin tries to provide a positive determination of the how the poetized distinguishes itself from the poem: not in principle, but 


\section{SAMUEL WEBER}

Vielmehr lediglich durch seine größere Bestimmbarkeit: nicht durch einen quantitativen Mangel an Bestimmungen, sondern durch das potentielle Dasein derjenigen, die im Gedicht aktuell vorhanden sind und anderer. (GS II.1, 106) Please note the last two words: und anderer. They are "angehängt" at the end of the sentence as a kind of afterthought, a kind of suffix not to a word this time but to the sentence. ${ }^{14}$ But what it does is very similar to what Benjamin effect of the poetized upon the poem: it brings about "eine Auflockerung der festen funktionellen Verbundenheit, die im Gedichte (hier: im Satz) selbst waltet...« (Ibid.) Let me try to paraphrase and also, since my time is up, to sum up the result of this all too brief reading: The "greater determinability « of the poetized - which is the object of the aesthetic commentary - consists first in the fact that it reinscribes the determinations that are "actually present " in the poem in a text that renders those determinations "possible«, "potential« virtual perhaps. But in so doing - in potentializing and virtualizing determination as determinability--the poetized cannot limit itself simply to the determinations actually present in the poem: it must also take into account "anderer". What those "other« determinations are Benjamin does not say - not here at least. But by suggesting that the poem is an attempt to resolve a task set by "life", he makes clear that the "inner form» of the poem cannot simply be internal to the poem itself, since the poem is a response to a challenge and task that antedates and transcends its singularity, while at the same time calling it into being.

The paradox here, as Benjamin puts toward the conclusion of this very long and complex paragraph, is that if the poem (and »life«) are characterized by "functional unity, «insight into the function presupposes the multiplicity of combinatorial possibilities [Verbindungsmöglichkeiten] «. Such an insight, however, is not construed by Benjamin as a synoptic view, but rather as the problematic result of an Absehen - a looking away from, rather than a looking toward: "Sie kann nicht anders entstehen als durch ein Absehen von gewissen Bestimmungen." The result is that in order to approach the poem with ever greater determinacy (Bestimmtheit), »das Gedichtete [muß] von gewissen Bestimmungen absehen.» $(106)^{15}$

14 In "The Task of the Translator, "Benjamin observes that the "sentence" is the "wall " before the original, whereas the "word" is the "arcade" opening passage to it. The adjunct here, "und anderer breaks open the walled-in meaning of the sentence, making it an open-ended passageway (GS IV.1, p. 18).

15 This recalls Freud's description of "Isolation" as a defense mechanism that does the same work as "repression" but while remaining within consciousness itself. See Sigmund Freud: "Inhibitions, Symptoms, Anxiety«, New York (Norton) 1959, pp. 47-49 (my translation, here as elsewhere -- S.W.). In this context it may be noted that Freud's earliest description of repression, in The Interpretation of Dreams, tended to describe it as an "Abwenden" - a word that in German can mean both "averting" one's eyes from something, as well as "warding off" the external danger itself (Sigmund Freud: Gesammelte Werke II/III, London 1948, p. 606). 


\section{BENJAMIN'S ABILITIES}

We see here, how the ability to be determined - the "greater determinability" of the poetized - depends directly on the ability to in-determine: to avert one's view from what cannot be taken in. This suggests how and why determinability, and Benjamin's -abilities more generally, go hand and hand with the negotiation of inability, and why looking up - der Augenaufschlag, as he writes in the Trauerspiel-book, ${ }^{16}$ always also means: looking away.

Perhaps it is this convergence of looking at, looking-away and looking-up that explains why the primary of Benjamin's abilities is that of readability. And also why the Now of Knowability - das Jetzt der Erkennbarkeit - is also the moment in which readability parts company with determinate meaning and knowledge, not by dissolving its relation to it, but by acknowledging the irreducible immediacy - the Un-mittel-barkeit - of its medium of language to be the greatest -ability of all.

16 GS I.1, p. 360: "Der ’Augenaufschlag`, den barocke Malerei "zu einem Schema« ausbildet, »das ganz unabhängig ist von der im augenblicklichen Vorwurf bedingten Situation«, verrät und entwertet die Dinge auf unaussprechliche Weise. Nicht sowohl Enthüllung als geradezu Entblößung der sinnlichen Dinge ist die Funktion der barocken Bilderschrift.» 